\title{
On the employment of marsh-gas for producing exceedingly low temperature
}

\section{Cailletet}

To cite this article: M. Cailletet (1885) On the employment of marsh-gas for producing exceedingly low temperature, Philosophical Magazine Series 5, 19:116, 65-65, DOI: $10.1080 / 14786448508627644$

To link to this article: http://dx.doi.org/10.1080/14786448508627644

曲 Published online: 29 Apr 2009.

Submit your article to this journal $₫$

Џll Article views: 2

Q View related articles $\asymp$ 


\section{$\left[\begin{array}{ll}65 & \end{array}\right]$ \\ X. Intelligence and Miscellaneous Articles.}

ON THE EMPLOYMENT OF MARSH-GAS FOR PRODUCING EXCEEDINGLY LOW TEMPERATURE. BY M. CAILLETET.

To the Editors of the Philosophical Magazine and Journal.

Gramlemen,

THAVE just received the September Number of the Philoso-

1 phical Magazine, in which I read with surprise a communication by Professor J. Dewar elaiming the priority for employing marshgas in order to obtain very low temperature. Mr. J. Dewar, to prove his claim, alludes to a note pulblished by him in 'Nature' of the 4th of October, 1853, which, he says, "will prove thut wy experiments with liquid marsh-gas were made a year in ahance of those made recently by M. Cailletet."

It is to be regretted that $\mathrm{Mr}_{\mathrm{r}} \mathrm{J}$. Dewar, who must be well acquainted with the contents of the communicatious presented by me to the French Academy of Sciences on the use of Marsh-gas, as well as the date of its presentation, has not spoken of the Notice I was obliged to publish a few weeks afterwards to refute the unjust claim of priority alleged by M. Wroblewski. This Note was deposited by me, closed and sealed, in the hands of the President of the French Academy on the 12th of December, 1881, that is to say, two years previous to the publication made by Mi. J. Dewar in 'Nature.' The Note was opened at my request and read in the Academical Meeting of the 4 th of last August. It contains these words :- " I am busy working up researches, at this moment, which will take me a long time, and will not be published before a lengthened period. I have been obliged to speak of the details of these researches to several persons; it is therefore quite uecessary for me to establish early my rights to priority in case any author were to take precedence, and for that object I write this note, which contains the summary of my work. I am trying to obtain greater cold than that obtained until now by scientific men.....

"By means of a pump, the piston-rod of which is covered with mercury, preventing thereby air and other injurious impediments, I can obtain the liquefaction of great quantities of carbonic acid and protoxide of nitrogen, as also of marsh-gas and ethylene, whose critical points are greatly inferior to those of carbouic acid. I am nearly certain to obtain very low temperature by plunging my instruments in these liquefied gases. I bope, lastly, to be able to liquefy oxygen, nitrogen, and other gases completely by refrigerating them by means of ethylene or marsh-gas boiling, atter having compressed them in a curved tube by employing the instrument invented by me and which is well known to the Academy."

This Note caunot leave, I trust, any doubt of the priority of my researches over those of Mr. J. Dewar; and it is certainly owing to his not having known it that he has published in the Philosophical Magazine the article which I feel entitled to answer.

L. Cailuetet,

Paris, 10 décembre, 1884.

Membre de l'Académie des Sciences.

Phil. Mag. S. 5. Vol. 19. No. 116. Jan. 1885. 